\title{
Hairy Vetch Growth-Promoting Rhizobium sp. RH84 and Application to Reclaimed Land
}

\author{
Jong-Ok Jang • Mi-Kyung Kwon • Dong-Jin Park • Chang Keun Sung • \\ Chang-Jin Kim*
}

\section{Rhizobium sp. RH84에 의한 간척지 환경에서의 헤어리베치 생육촉진}

장종옥·권미경 · 박동진 · 성창근 · 김창진*

Received: 16 May 2013 / Accepted: 23 July 2013 / Published Online: 31 December 2013

(C) The Korean Society for Applied Biological Chemistry 2013

\begin{abstract}
This study was carried out to investigate the plant growth promoting activity of hairy vetch (Vicia villosa Roth) on reclaimed land. At the previous research, Rhizobium sp. RH84 was isolated and selected for further study from hairy vetch. For the investigation of plant growth promoting effects by the Rhizobium sp. RH84, production of indole acetic acid (IAA), siderophore, phosphate solubilization and nitrogen fixation were tested and other characters were examined. As results, RH84 produced $9.03 \mu \mathrm{g}$ IAA per $\mathrm{mL}$ and showed nitrogen fixation activity. With the treatment of Rhizobium sp. RH84 to hairy vetch showed good growth at $0.3 \%$ salty reclaimed soil, and the production yield was increased up to $56 \%$ at field test. From these results, it was confirmed that the Rhizobium sp. RH84 would be used as a green manure for hairy vetch under the salty condition of reclaimed land.
\end{abstract}

Keywords hairy vetch · plant growth promoting activity · reclaimed land $\cdot$ Rhizobium sp. RH84

J. -O. Jang · D. -J. Park · C. -J. Kim

Korea Research Institute of Bioscience and Biotechnology, Deajeon 305333 , Republic of Korea

M. -K. Kwon

Chungcheongnam-do Agricultural Research and Extension Services, Agricultural Environment Research Division, Yesan 167, Republic of Korea

\section{J. -O. Jang $\cdot$ C. K. Sung}

Department of Food Science and Technology, Chungnam National University, Deajeon 305-764, Republic of Korea

*Corresponding author (C. -J. Kim: changjin@kribb.re.kr)
서 론

한국처럼 국토가 협소한 나라에서는 농업용지 활용으로서의 간 척지 개간 요구도가 높다. 그러나 간척지의 토성은 세립질 또 는 조립 세립질로 토양 배수가 불량하기 때문에(Baek 등, 2008) 염의 농도가 높고 그 분포가 불균일하여, 결국 재배작물의 염 해를 초래하게 된다. 또한, 간척지의 유기물 함량은 $1 \%$ 미만으 로 매우 낮아 농업용지로 사용하기 위해서는 유기물 함량의 증 가는 필수적이다. 콩과 작물인 헤어리베치(Vicia villosa Roth)는 대표적인 내한성 녹비작물로 뿌리혹에 공생하는 뿌리혹박테리 아에 의해 질소를 고정하며(Mueller와 Thorup-Kristensen, 2001), 낮은 C:N 비율로 분해가 빨라(Tobert 등, 1996) 우리나라의 겨 울철 휴경지에 적합한 식물이다. 그러나 일반적으로 콩과 작물 은 염분에 약하기 때문에(Greenway 와 Munns, 1980) 간척지에 적용 시 염해를 입을 수 있다. 앞의 연구에서 보고한 (Jang 등 , 2013) Rhizobium sp. RH84는 헤어리베치의 뿌리혹에서 유래 된 균주로 다른 분리 균주에 비해 헤어리베치의 뿌리혹 발달과 질소 고정력이 우수한 균주이었다. 일반적으로 헤어리베치와 공 생관계로 알려진 Rhizobium leguminosarum (Mothapo 등, 2013) 과는 유전적 유사성을 가지지만 더 높은 질소 고정력을 나타내 는 균주임을 보고하였다. 본 연구에서는 전보에서 분리된 Rhizobium sp. RH84를 이용하여 간척지 토양에서의 헤어리베 치 뿌리혹 형성능과 염에 대한 저항성을 증진시키고자 하였다. 더 나아가 간척지에 직접 적용함으로써 그 활용 가능성을 검토 하고자 하였다.

\section{재료 및 방법}

재료. 전북 부안군 새만금 계화도 간척지의 저염 $(0.05-0.1 \%)$, 중 염(0.1-0.6\%), 고염 $(0.7-0.8 \%)$ 흙을 채취하여, $121^{\circ} \mathrm{C}$ 에서 1 시간 
멸균한 후 dry oven에서 건조시켜 공시 토양으로 실험에 사용 하였다. 헤어리베치 종자는 농촌진흥청 국립식량과학원에서 개 발 육성된 청풍보라 품종을 분양 받아 사용하였다.

형태학적 및 생리생화학적 특성 분석. Rhizobium sp. RH84의 colony 형태, 그람 염색, 전자현미경(Transmission Electron Microscopy, TEM)을 통한 colony 관찰, 점액성 유무, bromothymol blue $(25 \mathrm{ppm})$ 를 이용한 산 생성 가능 유무를 확인하였다. 항생 제 내성도는 ampicillin, neomycin, spectinomycin, streptomycin, vancomycin 등 각 항생제에 대해서 각각 $10,25,50,100$ $\mathrm{ppm}$ 농도에서 분석하였다. 또한 API Kit (API ZYM, bioMerieux Inc., France)를 사용하여 추가적인 생리학적 특성을 분석 하였다.

Plant Growth Promoting (PGP) 활성 분석. PGP 활성능을 확인하기 위해서 옥신(auxin) 생산능, 질소 고정능, 인산 가용능, sideropore 생산능을 조사하였다. 식물생장촉진호르몬(IAA)인 옥 신은 salkowski 용액을 이용한 발색 정도를 측정하였다(Gordon 와 Weber, 1951). RH84 균주를 TSB $(0.05 \%$ tryptone, $0.03 \%$ yeast extract, $0.007 \%$ calcium chloride) 배지에 접종하여 $30^{\circ} \mathrm{C}$ 에서 24시간 전 배양 후 균체를 회수하였다. 옥신 생산 유도 전구체인 L-tryptophan이 $0.1 \%$ 가 첨가된 King's B 배지에 다시 접종하여 $30^{\circ} \mathrm{C}$ 에서 24 시간 진탕 배양하였다. 배양액을 원심분 리 $(8,000 \mathrm{rpm}, 15$ 분 $)$ 하여 상등액을 salkowski 용액 $\left(0.5 \mathrm{M} \mathrm{FeCl}_{3}\right.$ $1 \mathrm{~mL}, 35 \% \mathrm{HClO}_{4}$ )과 $1: 2$ 의 비율로 25 분간 상온의 암조건에서 반응하였다. 반응물은 $530 \mathrm{~nm}$ 에서 흡광도를 측정하였고(Ultrospec 3000, Amersham Pharmacia Biotech, UK), 옥신 표준물질 (Sigma, USA)과 비교하여 농도를 정량하였다. 질소 고정능은 nitrogen-free $\mathrm{NFb}$ 배지를 이용하여(Kirchhof 등, 1997) colony 주변의 막 형성 유무를 관찰하였다. 인산 가용능은 Pikovskaya's agar 배지 (Pikovskaya, 1948)에 난용성 인산염인 TCP (tricalcium phosphate)를 $0.5 \%$ 첨가한 배지에서 clear zone 형성 유무를 관 찰하였다. Siderophore 생산능은 Schwyn과 Neilands의 방법 (Schwyn과 Neilands, 1987)을 이용하여 CAS (chrome azurol S) blue 고체 배지에 접종 후 $30^{\circ} \mathrm{C}$ 에서 5 일간 배양하면서 orange halo zone 형성 유무를 관찰하였다.

간척지 토양에서의 뿌리혹 형성능 조사. 저염 $(0.05-0.1 \%)$ 의 간 척지 흙을 사용하였으며, 헤어리베치 종자는 경실 종자를 제거 후 표면 살균하여 실험하였다. 종자의 표면 살균은 $95 \%$ 에탄 올(Merck, USA)로 1분 30초, $2 \%$ sodium hypochlorite solution (JUNSEI, Japan)으로 3분간 처리 후 멸균된 증류수로 여러 번 세척하였다. Rhizobium sp. RH84는 YM agar 배지 상에서 34일간 배양 후 멸균 증류수로 회수하였다. 표면 살균한 종자에 $2 \times 10^{9} \mathrm{CFU} / \mathrm{mL}$ 농도의 균체 현탁액과 동량의 $2 \% \mathrm{CMC}$ (carboxymethyl cellulose)를 섞어 표면 살균한 종자에 코팅 후 파종하였다. 추가적으로 종자 코팅 농도와 같은 농도의 균체 현 탁액을 pot 당 $5 \mathrm{~mL}$ 씩 관주 접종하였다. 각 처리구는 4 반복으 로 하였고, $20-22^{\circ} \mathrm{C}$ 가 유지되는 유리 온실 내에서 자연광의 상 태로 8 주간 생육시킨 후 뿌리혹 형성 정도를 조사하였다.

염 농도별 간척지 토양에서의 생육촉진 효과. 간척지 흙을 염 농도별로 조제하여 Rhizobium sp. RH84처리 유무에 따른 헤어 리베치 생장 정도를 확인하였다. 저염, 중염, 고염의 간척지 흙 을 일정량씩 섞어 $0.05,0.1,0.15,0.2,0.23,0.3,0.35 \%$ 의 염 농도가 되게 조제하였다. 종자 표면 살균과 RH84 처리는 앞의 뿌리혹 형성능 조사에서와 동일한 방법으로 수행하였다. 각 처 리구는 3 반복하였고, $20-22^{\circ} \mathrm{C}$ 가 유지되는 유리 온실 내에서 자
연광의 상태로 14 주간 생육시킨 후 헤어리베치의 생체중을 조 사하였다.

간척지 포장에서의 생육촉진 효과. 본 실험은 2011 년 10 월 초 순에 파종하여 2012년 5월 하순경까지 전북 부안군 새만금 계 화도에 위치한 국립식량과학원 벼맥류부 간척지 농업과의 저염 시험포장 $(3 \mathrm{~m} \times 13 \mathrm{~m})$ 에서 실시하였다. 뿌리혹 형성능 실험에서 와 동일한 방법으로 조제된 Rhizobium sp. RH84 균주 현탁액 에 표면 살균 한 헤어리베치 종자를 5 분간 침지하여 건조 후, pearlite와 균주 현탁액을 섞어 만든 제제를 종자에 다시 도포하 였다. 무처리구는 RH84 대신 증류수로 대체하였다. 종자를 파 종한 후에는 종자 코팅과 동일한 농도의 RH84 현탁액을 $5 \mathrm{~mL}$ $\left(10^{9} \mathrm{cfu} / \mathrm{mL}\right)$ 씩 종자 주변에 추가 접종하였다. 각 구는 난괴법 으로 45 립씩 3 반복하였다. 성숙기의 헤어리베치를 채취 후, 각 시험구별로 생체중을 측정하여 처리구 당 평균치를 사용하였다.

\section{결과 및 고찰}

RH84의 형태학적 및 생리생화학적 특성 분석. Rhizobium sp. RH84의 형태학적 및 생리생화학적 특성은 Table 1, 2와 Fig. 1 에 나타내었다. RH84는 그람 음성의 간균으로 2-3개의 flagella 를 가지고 있었다. Colony는 희고 불투명하며 mucous를 형성 하였다. Bromothymol blue test는 노란색으로 변하는 것으로 보 아 산을 형성하는 것을 알 수 있었다. 항생제 내성 테스트 결 과 ampicillin, neomycin, spectinomycin, vancomycin에 대해서 내성이 없었고, streptomycin에 대해서는 $25 \mathrm{ppm}$ 농도까지 내성 을 나타내었다. API ZYM kit로 분석한 결과 alkaline phosphatase와 $\beta$-galactosidase활성은 양성, esterase lipase와 $\beta$ galactosidase활성은 음성으로 나타났다.

PGP 활성 분석. Rhizobacteria가 직접적으로 식물의 성장을 돕 는다는 연구(Lifshits 등, 1987)가 발표 된 이후 plant growth promoting rhizobacteria (PGPR)에 대한 연구는 여전히 활발하 다. 특히 식물과 $\mathrm{PGPR}$ 의 관계는 식물의 생장과 뿌리혹 형성에 영향을 미치기 때문에 더욱 중요하다(Egamberdieva 등, 2012; Safronova 등, 2012).

Rhizobium sp. RH84의 PGP 능을 분석하기 위해 식물생장호

Table 1 Morphological and physic-chemical characteristics of Rhizobium sp. RH84

\begin{tabular}{cc}
\hline Contents & Characteristics \\
\hline Morphological & Rod \\
Cell shape & Negative \\
Gram stain & $2-3$ \\
Flagella & White \\
Colony color & \\
Physico-chemical & + \\
Colony mucous & Yellow \\
Bromothymol blue test & \\
Antibiotic resistance & - \\
Ampicillin & - \\
Neomycin & - \\
Spectinomycin & 25 ppm \\
Streptomycin & - \\
Vancomycin &
\end{tabular}


Table 2 API ZYM test results of Rhizobium sp. RH84

\begin{tabular}{lc}
\multicolumn{1}{c}{ Charicteristics } & RH84 \\
\hline Alkaline phosphatase & + \\
Esterase (C 4) & - \\
Esterase Lipase (C 8) & - \\
Lipase (C 14) & - \\
Leucine arylamidase & + \\
Valine arylamidase & + \\
Cystine arylamidase & - \\
Trypsin & + \\
$\alpha$-chymotrypsin & - \\
Acid phosphatase & + \\
Naphthol-AS-BI-phosphohydrolase & - \\
$\alpha$-galactosidase & - \\
$\beta$-galactosidase & + \\
$\beta$-glucuronidase & - \\
$\alpha$-glucosidase & + -glucosidase \\
N-acetyl- $\beta$-glucosaminidase & + \\
$\alpha$-mannosidase & + \\
$\alpha$-fucosidase & - \\
\hline
\end{tabular}

+: positive, -: negative

르몬인 옥신의 생산능을 측정하였다. Rhizobium sp. RH84의 옥 신 생산량을 표준 물질과 비교한 결과 $9.03 \mu \mathrm{g} / \mathrm{mL}$ 의 옥신을 생 산하는 것으로 확인되었다. 옥신은 식물의 개화, 뿌리 성장, 열 매의 성숙 등 식물 생장의 중심적인 역할을 하며(Laskowski 등, 1995; Reinhardt 등, 2000), 옥신을 생산함으로써 RH84 균주가 헤어리베치의 생장을 촉진시키는 것으로 사료된다. 또한 nitrogen-free $\mathrm{NFb}$ 배지상의 colony 주변에 막이 형성된 것으로 보아 헤어리베치 뿌리혹의 질소 고정능 증가에도 영향을 미칠 것으로 사료된다(자료 미제시). 그러나 난용성인을 가용화시켜 식물의 생장에 도움을 주는(Hameeda 등, 2008) 인산가용능과 식물 병원균 억제기작인(Shobha와 Kumudini, 2012) sideropore 생산능은 없는 것으로 확인되었다.

간척지 토양에서 뿌리혹 형성능 조사. 새만금 간척지 토양의 토

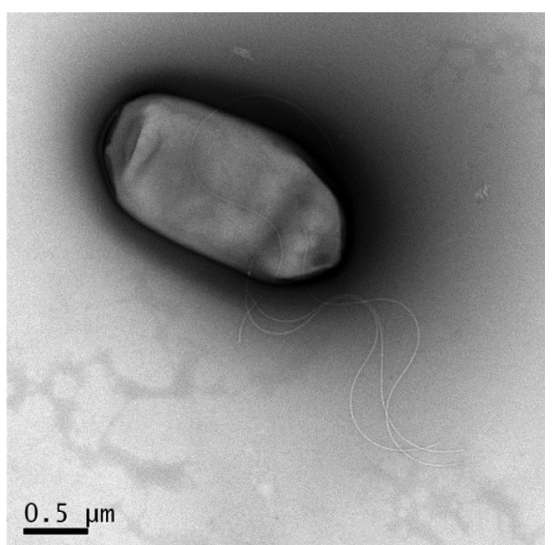

Fig. 1 Transmission electron microscopy of Rhizobium sp. RH84.

성은 세립질 또는 조립 세립질로 되어 있는 특성상 배수가 불 량하며 제염이 어렵다. 이러한 토양 조건에서 Rhizobium sp. RH84가 헤어리베치의 뿌리혹 형성에 영향을 주는지 분석하기 위하여 간척지 토양을 이용한 pot test를 실시하였다. 균주를 처 리한 8 주 후에 RH84 무처리구에서는 헤어리베치의 뿌리혹이 형성되지 않았지만(Fig. 2A), RH84 처리구에서는 뿌리혹이 형 성되었다(Fig. 2B). 그러므로 RH84는 간척지 토양에서도 질소 고정을 통한 헤어리베치 생육 촉진 효과를 나타낼 것으로 사료 된다.

염 농도별 간척지 토양에서의 생육촉진 효과 검정. 간척지를 밭 으로 이용 시 지하수위 및 배수조건에 따라 토양 표면의 염류 분포가 불균일하여 재배작물의 생육에 차이가 많이 나며, 일반 적인 작물재배 시 염 농도 $0.3 \%$ 이상에서는 작물의 생육에 심 한 저해가 일어나 재배가 불가능하다고 알려져 있다. 특히 헤 어리베치는 염에 약하여 $0.1 \%$ 염 농도 이하에서 재배하도록 권 장되고 있다(Kang, 2011). Rhizobium sp. RH84는 염 농도 $0.5 \%$ 에서 생육 가능한 균주 (전보 참조)로 염 농도가 높은 간 척지 토양에서도 잘 적응하여 헤어리베치의 생육 촉진에 기여 할 수 있을 것으로 기대되었다. 실험 결과, RH84 무처리구에서 는 $0.05-0.15 \%$ 의 염 농도에서 헤어리베치가 생장하였으며,

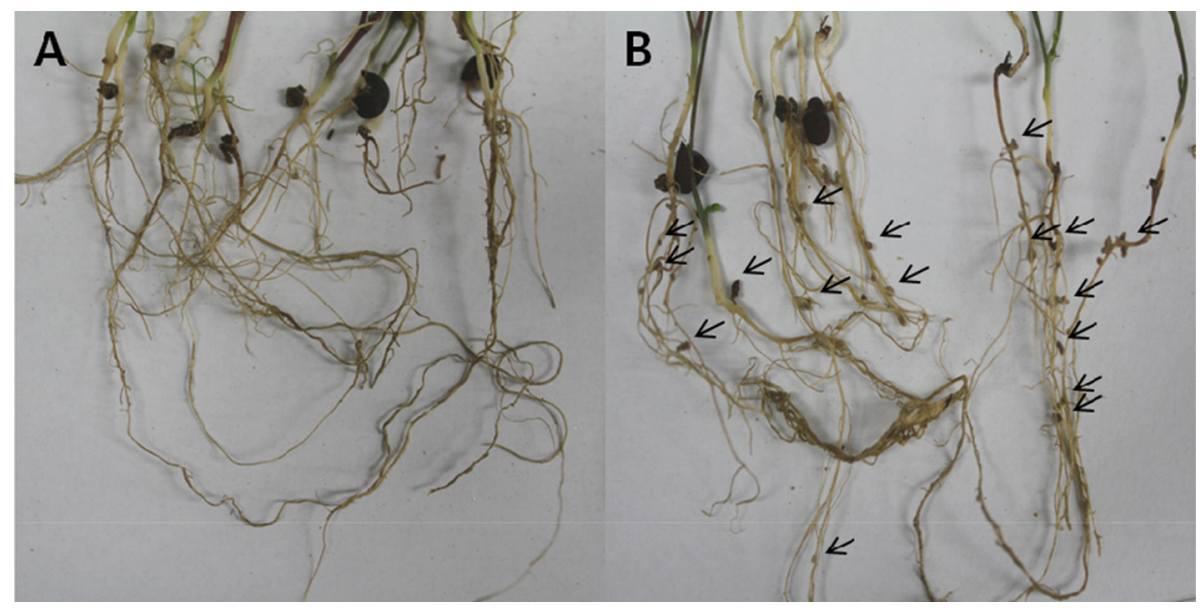

Fig. 2 Nodulation test of hairy vetch by Rhizobium sp. RH84. Test tube scale by artificial inoculation and using reclaimed land of soil. A; untreated, B; treated with Rhizobium sp. RH84. Arrow indicates nodule. 


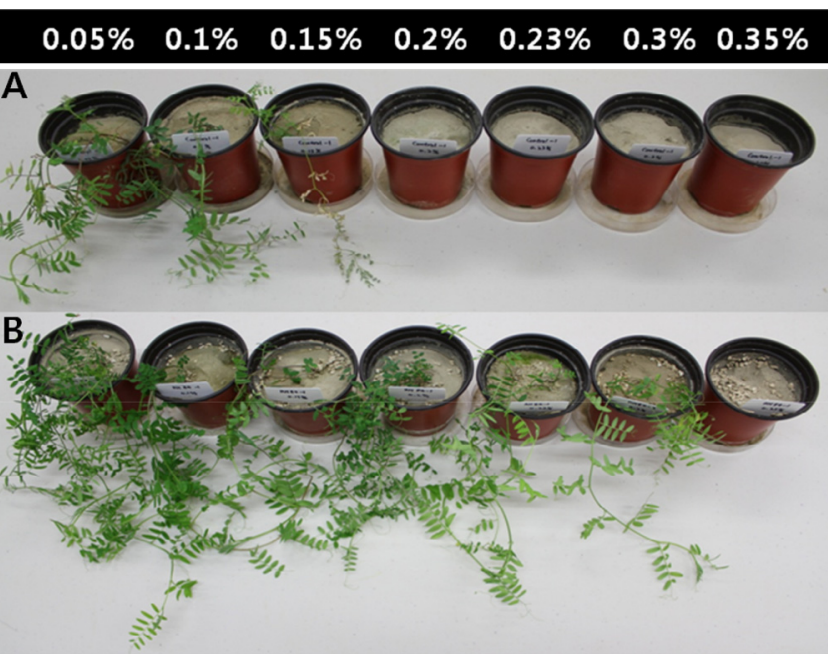

Fig. 3 The growth change of hairy vetch by Rhizobium sp. RH84 treatment with each $\mathrm{NaCl}$ concentration. A; untreated, B; treated with Rhizobium sp. RH84

Table 3 Plant growth promoting activities of Rhizobium sp. RH84

\begin{tabular}{lc}
\hline \multicolumn{1}{c}{ PGP content } & Activity \\
\hline IAA production & $9.03 \pm 0.3 \mu \mathrm{g} / \mathrm{mL}^{\mathrm{a}}$ \\
nitrogen fixation & $+^{\mathrm{b}}$ \\
Posphate solubilization & $-^{\mathrm{c}}$ \\
Sideropore production & $-^{\mathrm{d}}$ \\
\hline
\end{tabular}

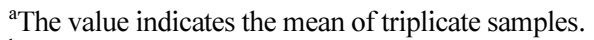

${ }^{\mathrm{b}} \mathrm{The}$ presence of a pellicle formation using semi-solid nitrogen-free $\mathrm{NFb}$ medium.

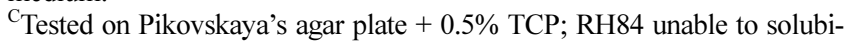
lize phosphate

${ }^{\mathrm{d}}$ Incubated in CAS agar plate; RH84 was non-sidrophore producer

$0.15 \%$ 이상의 농도에서는 생육하지 못하였다(Fig. $3 \mathrm{~A})$. 생체중 의 무게 또한 염 농도가 증가할수록 줄어드는 경향을 보였다 (Fig. 4). 그러나 RH84 처리구에서는 $0.3 \%$ 의 염 농도까지 헤어 리베치의 생장이 가능하며(Fig. 3B), 생체중의 무게 또한 무처 리구보다 증가하는 결과를 나타내었다(Fig. 4). 지금까지의 보고 에 의하면 헤어리베치 재배 시 토양 염 농도 $0.1 \%$ 이하에서는 양호한 생체수량을 보였고, $0.2 \%$ 이상에서는 녹비효과를 기대 하기 어려운 수준이며, 특히 토양 염 농도 $0.3 \%$ 이상에서는 수 확을 거의 기대할 수 없다고 알려져 있다(Kang, 2011). 그러나 본 연구에 의하면 Rhizobium sp. RH84 처리 시 $0.3 \%$ 의 염 농도에서도 헤어리베치의 생장을 촉진시킬 수 있을 것으로 기 대된다. 앞으로 파종 방법 및 제제화의 방법을 개선한다면 더 욱 다양한 염 농도의 간척지 환경에서도 헤어리베치의 생장이 가능하게 될 것으로 기대된다.

간척지 포장에서의 생육촉진 효과. 간척지 소포장에서의 적용 시험을 실시한 결과는 Fig. 5와 같이 무처리구(control)에서의 생 체중은 약 $12.7 \mathrm{~kg}$, Rhizobium sp. RH84 처리구의 생체중은 약 $22.7 \mathrm{~kg}$ 으로 약 $56 \%$ 증가하였다. 이는 RH84가 식물 호르몬인 옥신을 생산하며, 질소 고정능이 있기 때문에 헤어리베치의 생 장을 증가 시켰고, 그에 따라 생체중이 증가한 것이라 사료된다.

이상의 결과로, Rhizobium sp. RH84는 헤어리베치의 생장을

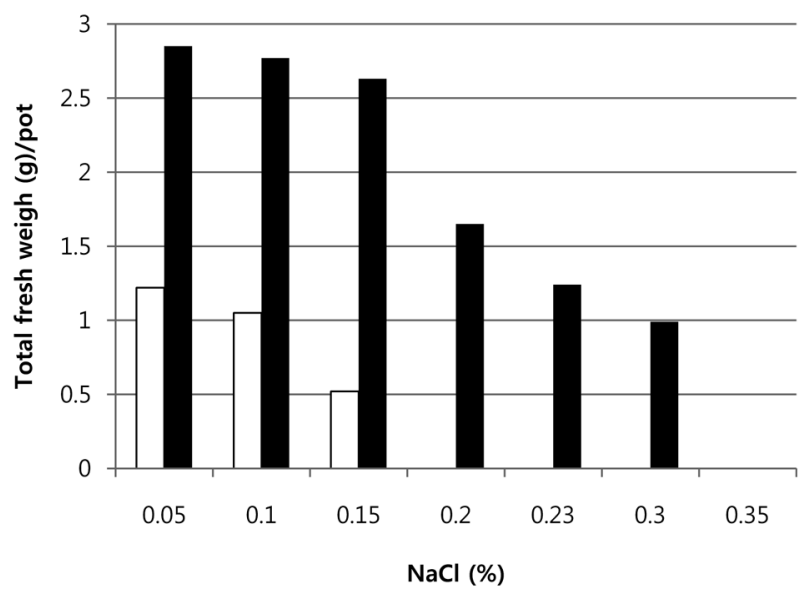

Fig. 4 Total fresh weight change of hairy vetch under each $\mathrm{NaCl}$ concentration. White bar means untreated and black bar means treated with Rhizobium sp. RH84.

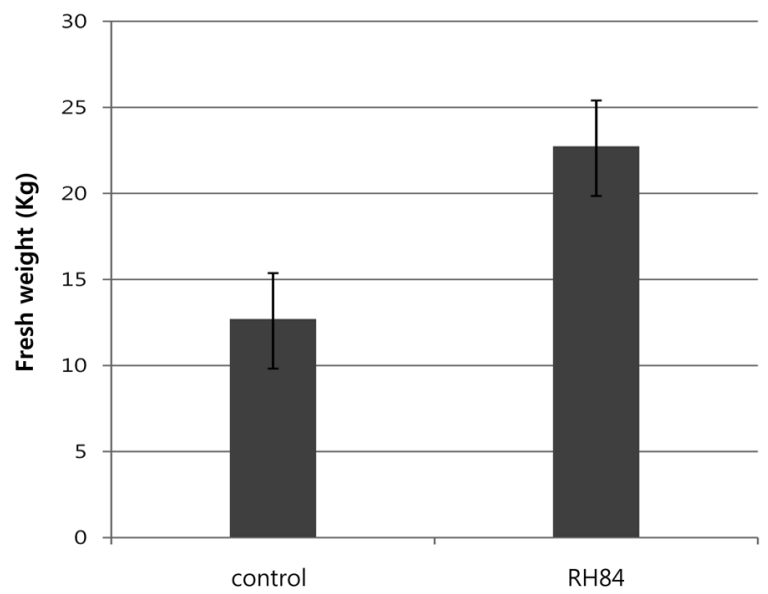

Fig. 5 Reclaimed land field test of Rhizobium sp. RH84 on hairy vetch

촉진하는 것으로 판단된다. 또한 RH84 처리에 의해 간척지 포 장에서의 헤어리베치의 생장을 증가시키는 것을 확인하였고, RH84 처리에 의해 $0.3 \%$ 염 농도 이상의 간척지에서도 생육을 기대할 수 있게 되었다. 더욱이 지금까지 헤어리베치의 생육 증 가에 대한 연구는 파종 시기(Kim 등, 2007; Ryoo, 2008) 혹은 품종 $(\mathrm{Kim}$ 등, 2004) 등에 대한 것으로 한정되어 있었다. 그러 나 본 연구에 의해 헤어리베치 유래의 rhizobacteria를 이용함으 로써 헤어리베치의 직접적 생육 증가를 가져올 것이며 그 활용 성 또한 더욱 높일 수 있을 것으로 사료된다. 또한 더욱 친환 경 적이고 지속 가능한 방법으로 간척지 토양의 개량에 기여할 것으로 사료된다.

\section{초 록}

녹비 작물인 헤어리베치의 간척지 적용을 위해 본 연구에서는 헤어리베치의 뿌리혹으로부터 분리 된 Rhizobium sp. RH84의 특성을 파악하고 이를 직접 간척지에 적용하여 헤어리베치의 생 산량 증대에 이용하고자 하였다. 전보에서 분리 한 RH84의 형 
태학적, 생리학적 특성 및 식물생육촉진(PGP) 활성을 확인하기 위하여 옥신, 질소 고정능, 인산 가용능, sideropore 생산능을 분 석하였다. 그 결과, RH84는 식물호르몬인 IAA를 $9.03 \mu \mathrm{g} / \mathrm{mL}$ 생산하였고, 질소 고정 활성을 가진 균주이었다. 또한 염 농도 가 $0.3 \%$ 인 간척지 토양에서의 헤어리베치 생장에 영향을 주며, 간척지 포장에서 약 $56 \%$ 의 헤어리베치 수확량을 증가시켰다. 따라서 Rhizobium sp. RH84 균주는 염 농도가 높은 간척지에 서 녹비작물인 헤어리베치의 생장을 촉진시키며 수확량을 증가 시키기 위한 균주임을 확인하였다.

감사의 글 본 연구는 농림수산식품부 농림기술개발사업에서 지원한 '호염 성 질소 고정균을 이용한 헤어리베치 생육촉진 및 이를 통한 간척지 녹비화 기술 개발'과 미래창조과학부 국제공동연구사업인 '해외생물소재 확보 및 활 용'사업의 연구비 지원에 의해 수행되었습니다.

\section{References}

Baek SH, Lee SU, Kim DG, Heo JW, and Kim SD (2008) Influence of Gypsum, popped rice hulls and zeolite on contents of cation in reclaimed tideland soils in Mangyeong. Korean J Environ Agric 27, 321-7.

Egamberdieva D, Berg G, Lindstrom K, and Rasanen LA (2012) Alleviation of salt stress of symbiotic Galega officinalis L. (goat's rue) by coinoculation of Rhizobium with root-colonizing Pseudomonas. Plant soil 369, 453-65.

Gordon SA and Weber RP (1951) Colorimetric estimetion of indole acetic acid. Plant Physiol 26, 192-5.

Greenway H and Munns R (1980) Mechanisms of salt tolerance in nonhalophytes. Аппи Rev Plant Physiol 31, 149-90.

Hameeda BG, Rupela OP, Wani SP, and Reddy G (2008) Growth promotion of maize by phosphate solubilizing bacteria isolated from composte and macro-fauna. Microbiol Res 163, 234-42.

Jang JO, Kwon MK, Park DJ, Sung CK, and Kim CJ (2013) Screening of Rhizobium sp. of hairy vetch root nodule bacteria with promotion of nodulation and nitrogen fixation. Kor J Microbiol in press.

Kang JK (2011) Reclaimed land utilization technology of green manure crops. In Reclaimed land cultivation and the use of green manure crops, Lim SJ (ed.), National Institute of crop Science 63-4, RDA, Korea.
Kim JG, Chung ES, Lim YC, Seo S, Kim MJ, and Kim JD (2004) Studies on the comparison of agronomic characteristics and productivity in induced vetch cultivar. J Korean Grassl Sci 24, 177-82.

Kim SJ, Kim IS, and Lee JS (2007) Effect of autumn seedling date on the productiviry and feed values of hairy vetch (Vicia villosa Roth.) varieties. Kor J Organic agric 15, 59-69.

Kirchhof G, Reis VM, Baldani JI, Eckert B, Dobereiner J, and Hartmann A (1997) Occurrence, physiological and molecular analysis of endophytic diazotrophic bacteria in gramineous energy plant. Plant and Soil 194, $45-55$.

Laskowski M, Williams M, Nusbaum H, and Sussex I (1995) Formation of lateral root meristems is a two-stage process. Development 121, 330310.

Lifshits R, Joseph WK, Maya K, Catherine S, John C, Elizabeth M T et al. (1987) Growth promoting of canola (rapeseed) seedling by a strain of Pseudomonas putida under gnotobiotic condition. Can J Microbiol 33, $390-5$.

Mothapo NV, Grossman JM, Maul JE, Shi W, and Isleib T (2013) Genetic diversity of resident soil rhizobia isolated from nodules of distinct hairy vetch (Vicia villosa Roth) genotypes. Appl Soil Ecol 64, 201-13.

Mueller T and Thorup-Kristensen K (2001) N-fixation of selected green manure plants in an organic crop rotation. Biol Agric Hort 18, 345-63.

Pikovskaya RI (1948) Mobilization of phosphorous in soil in connection with the vital activity of some microbial species. Mikrobiologiya 17, 362-70.

Reinhardt D, Mandel T, and Kuhlemeier C (2000) Auxin regulates the initiation and radial position of plant lateral organs. Plant Cell 12, 50718.

Ryoo JW (2008) Growth characteristics and green manure productivities of hairy vetch and woolly pot vetch under different sowing seasons in the highland area. Kor J Organic agric 16, 409-20.

Safronova VI, Piluzza G, Zinovkina NY, Kimeklis AK, Belimov AA, and Bullitta S (2012) Relationships between pasture legumes, rhizobacteria and nodule bacteria in heavy polluted mine waste of SW Sardinia. Symbiosis 58, 149-59.

Schwyn B and Neilands JB (1987) Universal chemical assay for the detection and determination of siderophores. Analytical Biochem. 160, 47-56.

Shobha G and Kumudini BS (2012) Antagonistic effect of the newly isolated PGPR Bacillus spp. on Fusarium oxysporum. Int. Journal of Applied Science and Engineering Research 1, 463-74.

Tobert HA, Reeves DW, and Mulvaney RL (1996) Winter legume cover crop benefits to corn rotation vs. fixed-nitrogen effects. Agron $J \mathbf{8 8}, 527-35$. 